\title{
Injection Molded of Bio-Micro-Composites from Natural Fibers and Polylactic Acid
}

\author{
Subyakto, Euis Hermiati, Nanang Masruchin, Ismadi, Kurnia Wiji Prasetiyo, \\ Wida Banar Kusumaningrum, and Bambang Subiyanto
}

\begin{abstract}
Green composites were needed by automotive industries because they are environmentally friendly, recyclable, lightweight and strong. Natural fibers such as bamboo and sisal are potential source of these materials and can be used as substitutes of fiber glass which is hard to recycle and not renewable. In this experiment, bio-composites made from micro fibers of betung bamboo (Dendrocalamus asper) and sisal (Agave sisalana) mixed with a natural polymer of polylactic acid (PLA) were developed that may used for automotive application. Bamboo or sisal fibers were converted into pulp and processed using a disc refiner to produce microfibrillated cellulose (MFC) with fiber diameter around $10 \mu \mathrm{m}$. MFC was mixed with PLA and triacetin and dried. The mixture was processed in a mixer at temperature of $170^{\circ} \mathrm{C}$, speed of $60 \mathrm{rpm}$ for $20 \mathrm{~min}$. The compound mixture was removed and processed into pellets using a pelletizer at $170^{\circ} \mathrm{C}$. Pellets were processed using injection molding machine. The compositions of fibers/PLA were 10/90, 20/80, and 30/70. The mechanical properties were tested in accordance with ASTM standards. Result shown that optimum composition ratio of bamboo fibers/PLA was 20/80 which gave flexural strength of $62.30 \mathrm{MPa}$, flexural modulus of $3.89 \mathrm{GPa}$, tensile strength of $44.55 \mathrm{MPa}$, tensile modulus of $1.20 \mathrm{GPa}$, and hardness of $112.90 \mathrm{R}$. While the optimum composition ratio of sisal fibers/PLA was 30/70 which gave flexural strength of $67.83 \mathrm{MPa}$, flexural modulus of $4.43 \mathrm{GPa}$, tensile strength of $48.18 \mathrm{MPa}$, tensile modulus of $1.13 \mathrm{GPa}$, and hardness of $110.50 \mathrm{R}$.
\end{abstract}

Key words: natural fibers, micro size, polylactic acid, injection, composites

\section{Introduction}

Green composites made from natural polymer reinforced with natural fibers has been subjected to many studies. This environmentally sound composites can be used for many applications, includes for automotive parts. Automotive industries grow rapidly in the world. In 2007 world production of cars is 52.1 million units, increased from 49.1 million units in 2006. If trucks are included the total production in 2007 is 74.1 million units and predicted to increase to 84 million units in 2008 (Renner 2008). Therefore materials to support these industries will be very huge and important. Now there is a trend for automotive industries to reduce utilization of materials that polluted the environment such as fiber glass, carbon and aramid fibers and substitute them with "green" materials such as natural fibers. The European Union End of Life of Vehicles (ELV) program requires that in the year of 2015 all new cars should have $95 \%$ recyclable materials (Marsh 2003). This means composites reinforced with natural fibers will play important role and might be a revolutionary material of this century (Marsh 2003). Some advantages using natural fibers compared to synthetic fibers are renewable, biodegradable, recyclable, non toxic to environment and health, lighter density, better mechanical properties, non abrasive to tools, and lower price (Leao et al. 1998; Mohanty et al. 2002; Oksman et al. 2003; Wambua et al. 2003; Mueller and Krobjilowski 2003; Zimmermann et al. 2004; Suddell and Evans 2005; Bismarck et al. 2005; Bogoeva-Gaceva et al. 2007; John and Thomas 2008). Utilization of natural fibers reduce car weight up to $40 \%$, lower energy to produce natural fiber (4 GJ/ton) compare to glass fiber ( $30 \mathrm{GJ} / \mathrm{ton}$ ), and production of glass fiber release toxic gases such as $\mathrm{CO}_{2}, \mathrm{NO}_{x}, \mathrm{SO}_{x}$ and dust (Marsh 2003; Suddell and Evans 2005). While many advantages are obtained of using natural fibers for composite, some drawbacks are realized. Natural fibers are hydrophilic in character, when it combined with polymer matrix that are hydrophobic then they have a lower compatibility. Natural fibers are also required low processing temperature to about $200^{\circ} \mathrm{C}$ to prevent fiber degradation (Nakagaito et al. 2005). To overcome the drawbacks, addition of coupling agent in the matrix and improve processing methods are applied. Biocomposite from natural fibers and polymer matrix for automotive materials have been studied intensively (Leao et al. 1998; Mohanty et al. 2002; Wambua et al. 2003, Misra et al. 2004, Suddell and Evans 2005, Bledzki et al. 2006). Research on composite from raw fibers of sisal and bamboo have been done (Li et al. 2000; Mohanty et al. 2004a; Mohanty et al. 2004b; Okubo et al. 2004; Shibata et al. 2008; Okubo et al. 2009; Huang et al. 2009)

Compression molding is the main process in the production of automotive parts when using natural fiber composites, while only a little using injection molding process (Nystrom et al. 2007). However some research had been done on natural fiber composites using injection molding for general purposes (Chow et al. 1998; Arzondo et al. 2004; Arzondo et al. 2005; Godavarti 2005; Mutje et al. 2006; Panthapulakkal and Sain 2007).

Polylactic acid is polymer made from renewable materials such as corn (Oksman et al. 2003). Composites made from this polymer which reinforced with natural fibers 
will produce totally green composites (Ljungberg and Wesslen 2002; Mathew et al. 2005; Iwatake et al. 2008; Suryanegara et al. 2009). The purpose of this research is to develop injection molded materials from natural fibers of sisal, bamboo and green polymer of polylactic acid that may used for automotive application. Effect of fiber ratio on the mechanical properties and morphological characteristic are observed.

\section{Materials and Methods}

\section{Microfibrillated Cellulose Preparation}

Betung bamboo (Dendrocalamus asper) and sisal (Agave sisalana) were obtained from Bogor and Blitar, respectively. Bamboo and sisal fibers were processed into pulp using chemicals and bleached. Sisal fibers were cut into $3 \sim 5 \mathrm{~cm}$ fibers and pulped using kraft process with $20 \%$ active alkali and $30 \%$ sulfidity. Cooked liquors were $18.06 \%$ $\mathrm{NaOH}$ and $7.55 \% \mathrm{~N}_{2} \mathrm{~S}$ with ratio of materials to liquor was 1 : 5. Cooking time was 3 hours at $160^{\circ} \mathrm{C}$. Bamboo was crushed to obtain $5 \mathrm{~cm}$ length fiber bundles. Kraft pulping process was used with $15 \sim 17 \%$ active alkali and $22.5 \sim 25.0 \%$ sulfidity. Cooked liquors were $18.06 \% \mathrm{NaOH}$ and $7.55 \% \mathrm{~N}_{2} \mathrm{~S}$ with ratio of materials to liquor was $1: 4$. Cooking time was 3.5 hours at $165^{\circ} \mathrm{C}$. Bleaching process was conducted at three steps. For sisal, first step using $2.14 \% \mathrm{Cl}_{2}$ at room temperature for $60 \mathrm{~min}$, second steps using $1.5 \% \mathrm{NaOH}$ at $70^{\circ} \mathrm{C}$ for $90 \mathrm{~min}$, and the last step using $4 \%$ hypochlorite at $40^{\circ} \mathrm{C}$ for $180 \mathrm{~min}$. For bamboo, first step using $4.68 \% \mathrm{Cl}_{2}$ at room temperature for $60 \mathrm{~min}$, second steps using $1.5 \% \mathrm{NaOH}$ at $60^{\circ} \mathrm{C}$ for $60 \mathrm{~min}$, and the last step using $4 \%$ hypochlorite at $40^{\circ} \mathrm{C}$ for $180 \mathrm{~min}$. Bleached pulp was processed further in a disc refiner using water for 5 cycles to produce microfibrillated cellulose (MFC) with fiber diameter around $10 \mu \mathrm{m}$.

\section{Composites Preparation}

Polylactic acid (Lacea H400, Mitsui Co. Japan) was dissolved in Dichloromethane in a reaction jar using stirrer. After PLA dissolved, wet pulp and Triacetin were put in and stirred until homogenous. The mixture was dried in an oven $60^{\circ} \mathrm{C}$ for $6 \mathrm{~h}$. Dried mixture was processed further in a mixer (Haake Reocord 90) at temperature of $170^{\circ} \mathrm{C}$, speed of 60 rpm for $20 \mathrm{~min}$. The mixture was removed and processed into pellets using a pelletizer (Laboplastomill 30R150) at $170^{\circ} \mathrm{C}$. Pellets were processed using injection molding machine (Nissei Plastic Industrial Co. Ltd. PS60E9ASE) to make test samples of bending, tensile, and hardness. Injection parameters were: injection temperatures of $140 \sim 150^{\circ} \mathrm{C}$, injection pressure of $45 \sim 50 \%$, injection speed of $30 \sim 40 \%$, injection time of $10 \mathrm{~s}$. The compositions of fibers/PLA were 10/90, 20/80, and 30/70. Triacetin added was $7 \%$ of the composite weight.

\section{Testing}

The mechanical properties were tested in accordance with ASTM standards (ASTM D790: flexural test, ASTM D638: tensile test, ASTM D785: hardness test). Scanning electron microscope (JEOL JSM 5310LV Japan) was used to observe the fracture surface of the composites.

\section{Results and Discussion}

\section{Microfibrillated Cellulose of Sisal and Bamboo}

Fibers in natural fibers usually formed in bundles (50 100 $\mu \mathrm{m}$ in diameter) contains of single fiber with diameter size of 10 20 $\mu \mathrm{m}$ and can be fibrillated further into crystal cellulose with diameter size of $4 \sim 10 \mathrm{~nm}$. The smaller diameter of fiber the stronger (Zimmermann et al. 2004, Nakagaito and Yano 2004). For example fiber of wood pulp has modulus elasticity of $10 \mathrm{GPa}$, however in the form of crystal structure the modulus elasticity is 130 250 GPa. Mechanical process combined with chemical process are used to make micro or nano fibers (Abe et al. 2007). Microfibrillated cellulose is first introduced by Turbak et al. (1983). Microfibrillated cellulose of sisal and bamboo were prepared from bleached kraft pulp that processed using disc refiner for 5 cycles. The diameter size of fiber is less than 10 $\mu \mathrm{m}$ (Subyakto et al. 2009) therefore called micro fibers. While the fiber length of sisal is about $1.4 \mathrm{~mm}$ (Munawar 2008) and bamboo is about $0.5 \sim 2.0 \mathrm{~mm}$. This gave high aspect ratio (length/diameter) and when use for reinforcement will result in strong composites (Zimmermann et al. 2004; Zhang et al. 2010). Zhang et al. (2010) studied deeply the properties of microfibrillated cellulose from bamboo (Phyllostachys pubescens) pulp.

\section{Mechanical Properties of Bio-micro Composites}

Results of bending, tensile, and hardness properties are presented in Table 1, 2, and 3, respectively. It is shown that composites made from sisal or bamboo yielded in almost similar properties, even though in some properties sisal performed better compare to bamboo.

Flexural (bending) properties of composites increases with increasing fiber ratio in sisal/PLA composites, while in the bamboo/PLA composites performed optimally in ratio of $20 / 80$ (Table 1). The flexural strength of sisal/PLA composites ranges from $61.78 \mathrm{MPa}$ to $67.83 \mathrm{MPa}$, and the flexural modulus ranges from $3.11 \mathrm{GPa}$ to $4.43 \mathrm{GPa}$. In the bamboo/PLA composites, the flexural strength ranges from $55.59 \mathrm{MPa}$ to $62.30 \mathrm{MPa}$, and the flexural modulus ranges from $3.77 \mathrm{GPa}$ to $3.89 \mathrm{GPa}$. These flexural properties obtained from injection molded specimens were lower than hot press molded specimen using the same materials (Subyakto et al. 2010). Using hot press molding, the flexural strength and flexural modulus of sisal/PLA are 61.54 100.42 MPa and 5.77 8.07 GPa, respectively. 
Table 1. Results of flexural properties of micro-composites using injection molding.

\begin{tabular}{lccc}
\hline Composite Type & $\begin{array}{c}\text { Max Load } \\
(\mathrm{N})\end{array}$ & $\begin{array}{c}\text { Flexural Strength } \\
(\mathrm{MPa})\end{array}$ & $\begin{array}{c}\text { Flexural Modulus } \\
(\mathrm{GPa})\end{array}$ \\
\hline Sisal/PLA: $10 / 90$ & $212.6(6.4)$ & $62.49(2.03)$ & $3.11(0.23)$ \\
Sisal/PLA: $20 / 80$ & $208.3(2.8)$ & $61.78(1.12)$ & $3.37(0.09)$ \\
Sisal/PLA: $30 / 70$ & $227.2(18.6)$ & $67.83(4.94)$ & $4.43(0.28)$ \\
Bamboo/PLA: $10 / 90$ & $195.1(14.6)$ & $58.15(4.14)$ & $3.88(0.08)$ \\
Bamboo/PLA: $20 / 80$ & $208.6(11.7)$ & $62.30(3.50)$ & $3.89(0.07)$ \\
Bamboo/PLA: $30 / 70$ & $187.3(8.2)$ & $55.59(2.56)$ & $3.77(0.16)$ \\
\hline
\end{tabular}

${ }^{*}$ Figures in the brackets are standard deviations

Table 2. Results of tensile properties of micro-composites using injection molding.

\begin{tabular}{lccc}
\hline Composite type & $\begin{array}{c}\text { Yield Strain } \\
(\%)\end{array}$ & $\begin{array}{c}\text { Tensile Strength } \\
(\mathrm{MPa})\end{array}$ & $\begin{array}{c}\text { Tensile Modulus } \\
(\mathrm{GPa})\end{array}$ \\
\hline Sisal/PLA: $10 / 90$ & $5.68(0.13)$ & $43.04(0.88)$ & $0.95(0.08)$ \\
Sisal/PLA: $20 / 80$ & $5.49(0.08)$ & $42.69(2.53)$ & $1.14(0.16)$ \\
Sisal/PLA: $30 / 70$ & $5.52(0.14)$ & $48.18(0.62)$ & $1.13(0.12)$ \\
Bamboo/PLA: $10 / 90$ & $5.95(0.23)$ & $41.58(4.09)$ & $1.05(0.06)$ \\
Bambo/PLA: $20 / 80$ & $5.53(0.18)$ & $44.55(0.66)$ & $1.20(0.14)$ \\
Bamboo/PLA: $30 / 70$ & $5.41(0.10)$ & $43.79(1.54)$ & $1.23(0.09)$ \\
\hline
\end{tabular}

${ }^{*}$ Figures in the brackets are standard deviations.

Table 3. Results of hardness of micro-composites using injection molding.

\begin{tabular}{lc}
\hline Composite Type & Hardness $(\mathrm{R})$ \\
\hline Sisal/PLA: $10 / 90$ & $118.0(0.35)$ \\
Sisal/PLA: 20/80 & $117.5(0.94)$ \\
Sisal/PLA: $30 / 70$ & $110.5(1.32)$ \\
Bamboo/PLA: $10 / 90$ & $118.1(1.29)$ \\
Bamboo/PLA: $20 / 80$ & $112.9(0.96)$ \\
Bamboo/PLA: $30 / 70$ & $112.7(0.45)$ \\
\hline
\end{tabular}

* Figures in the brackets are standard deviations.

While that of bamboo/PLA are 73.31 105.23 MPa and $6.11 \sim 7.06 \mathrm{GPa}$, respectively. The decrease may due to the processing method, where in injection molding process, the material processed in pelletizer before injection which may reduce the bond between fibers and PLA. For flexural properties, the optimal ratio of sisal MFC/PLA is 30/70, while that of bamboo MFC/PLA is 20/80.

Table 2 showed that tensile properties of composites are optimal in ratio of sisal MFC/PLA of 30/70 and bamboo MFC/PLA of 20/80. The yield strain decreased with increasing fiber ratio or decreasing of PLA as matrix, because PLA has higher yield strain compare with sisal or bamboo fibers. The tensile strength obtained in this experiment are range of $42.69 \sim 48.18 \mathrm{MPa}$ for sisal MFC/PLA and 41.58 44.55 MPa for bamboo MFC/PLA. Lee et al. (2004) obtained lower value about $35 \mathrm{MPa}$ of tensile strength of composite PLA-bamboo fiber using hot press molding. This may due to the size of bamboo fiber they used (fiber bundle with diameter of $70 \mu \mathrm{m}$ ). In this experiment we used smaller diameter of fiber around 10 $\mu \mathrm{m}$. The tensile modulus of this experiment range from
0.95 1.14 GPa for sisal MFC/PLA composites and 1.05 1.23 GPa for bamboo MFC/PLA composites. This values of tensile modulus are lower compare to that obtained by Lee et al. ( 2004) about $2.7 \mathrm{GPa}$.

Table 3 presented the hardness results of composites of sisal MFC/PLA and bamboo MFC/PLA at various fiber ratios. For sisal MFC/PLA composites the highest value of hardness obtained from ratio of $10 / 90$, similarly with bamboo MFC/PLA composites. This my due to the character of fibers which has high aspect ratio of length to diameter. In the flexural and tensile properties, this aspect ratio has significant effect as reinforced agent of the composites. However in hardness this effect may not significant, where PLA as matrix is more dominant.

\section{Scanning Electron Microscope Observation}

SEM observation of fracture surface of composites are presented in Figure 1 for sisal MFC/PLA and Figure 2 for bamboo MFC/PLA. It is shown that in all fiber ratios the mixture between fibers and PLA are homogenous. 


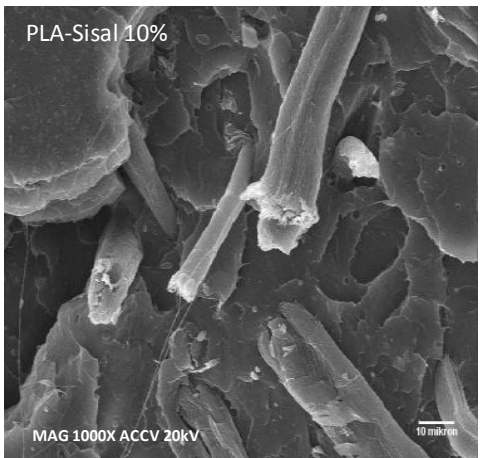

(A)

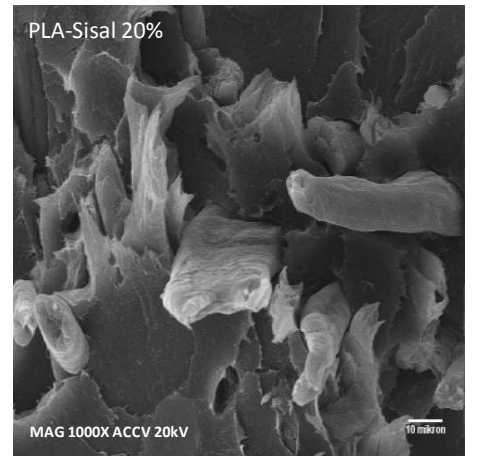

(B)

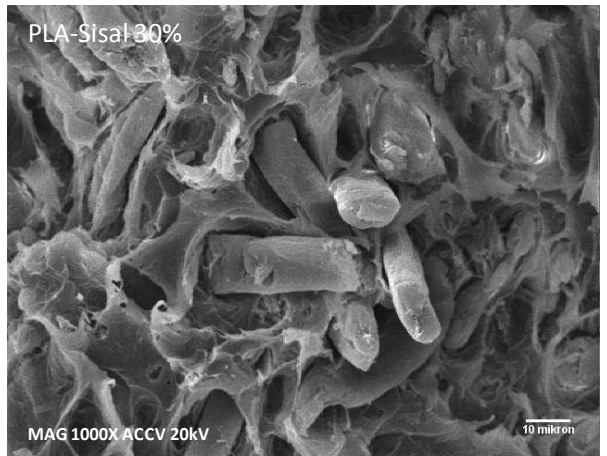

(C)

Figure 1. SEM micrographs of fracture surface of bio-micro composites at sisal MFC/PLA ratio of 10/90 (A), 20/80 (B), and $30 / 70(C)$.

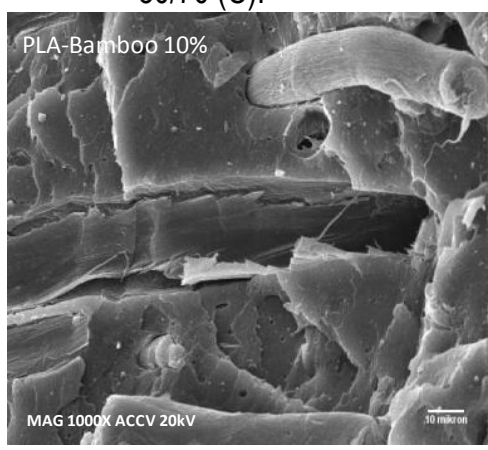

(A)

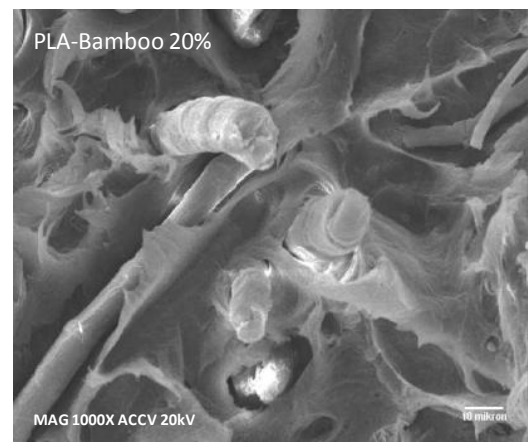

(B)

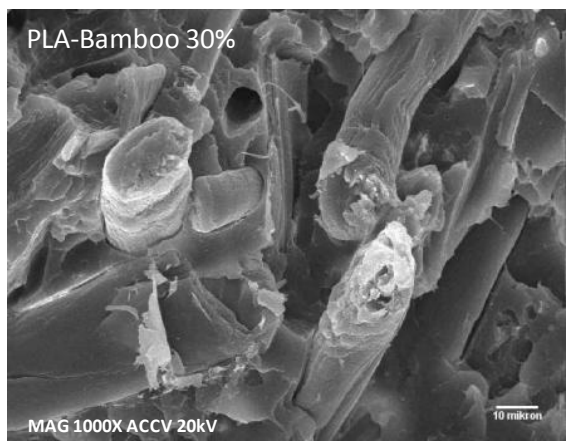

(C)

Figure 2. SEM micrographs of fracture surface of bio-micro composites at bamboo MFC/PLA ratio of 10/90 (A), 20/80 (B), and $30 / 70$ (C).

\section{Conclusions}

Bio-micro composites from micro fibers of sisal, bamboo and polylactic acid was developed using injection molding machine. Effect of fiber ratio on the mechanical properties and morphological characteritics were observed. The results showed that the optimum composition of sisal MFC/PLA is $30 / 70$, while that of bamboo MFC/PLA is 20/80. SEM observation showed that in all compositions the mixture between fibers and PLA are homogenous.

\section{References}

Abe, K.; S. Iwamoto; H. Yano. 2007. Obtaining Cellulose Nanofibers with A Uniform Width of $15 \mathrm{~nm}$ from Wood. Biomacromolecules 8: 3276-3278.

Arzondo, L.M.; C.J. Perez; J.M. Carella. 2005. Injection Molding of Long Sisal Fiber-reinforced Polypropylene: Effects of Compatibilizer Concentration and Viscosity on Fiber Adhesion and Thermal Degradation. Polymer Eng. and Sci. 2005:DOI 10.1002/pen.20299.

Arzondo, L.M.; A. Vazquez; J.M. Carella; J.M. Pastor. 2004. A Low Cost, Low-fiber-breakage, Injection Molding Process for Long Sisal Fiber Reinforced Polypropylene. Polymer Eng. and Sci. 44 (9): 17661772.
Bismarck, A.; S. Mishra; T. Lampke. 2005. Plant Fibers as Reinforcement for Green Composites. In: Natural Fibers, Biopolymers, and Biocomposites (Eds.: Mohanty, Misra, Drzal). CRC Press. p. 37-108.

Bledzki, A.K.; O. Faruk; V.E. Sperber. 2006. Cars from BioFibers. Macromol. Mater. Eng. 291:449-457.

Bogoeva-Gaceva, G.; M. Avella; M. Malinconico; A. Buzarovska; A. Grozdanov; G. Gentile; M.E. Errico. 2007. Natural Fiber Eco-composites. Polymer Composites-2007. DOI 10.1002/pc.

Chow, P.; D.S. Bajwa; W. Lu; J.A. Youngquist; N.M. Stark; Q. Li; C.G. Cook. 1998. Injection-molded Composites from Kenaf and Recycled Plastic. Proceedings of $1^{\text {st }}$ Annual American Kenaf Society Meeting, San Antonio, TX, February 1998, pp. 38-42.

Godavarti, S. 2005. Thermoplastic Wood Fiber Composites. In: Natural Fibers, Biopolymers, and Biocomposites (Eds.: Mohanty, Misra, Drzal). CRC Press. pp. 347389.

Huang, X.; A. Netravali. 2009. Biodegradable Green Composites Made Using Bamboo Micro/nano-fibrils and Chemically Modified Soy Protein Resin. Composites Science and Technology 69:1009-1015.

Iwatake, A.; M. Nogi; H. Yano. 2008. Cellulose NanofiberReinforced Polylactic Acid. Composites Science and Technology 68: 2103-2106. 
John, M.J.; S. Thomas. 2008. Biofibres and Biocomposites. Carbohydrate Polymer 71: 343-364.

Leao, A.L.; R. Rowell; N. Tavares. 1998. Applications of Natural Fibers in Automotive Industries in Brazil Thermoforming Process. Prasad et al. (eds). Science and Technology of Polymer and Advanced Materials. Plenum Press, New York. pp. 755-761.

Lee, S.H.; T, Ohkita; K. Kitagawa. 2004. Eco-composite from Poly (Lactic Acid) and Bamboo Fiber. Holzforschung 58: 529-536.

Li, Y.; Y.W. Mai; L. Ye. 2000. Sisal Fibre and Its Composites: A Review of Recent Developments. Composite Science and Technology 60: 2037-2055.

Ljungberg, N.; B, Wesslen. 2002. The Effects of Plasticizers on the Dynamic Mechanical and Thermal Properties of Poly (Lactic Acid). J Applied Polymer Science 86: 1227-1234.

Marsh, G. 2003. Next Step for Automotive Materials. Materialstoday, April 2003, Elsevier Science Ltd. pp. 36-43.

Mathew A.P.; K. Oksman; M. Sain. 2005. Mechanical Properties of Biodegradable Composite from Poly Lactic Acid (PLA) and Microcrystalline Cellulose (MCC). J Applied Polymer Science 97: 2014-2025.

Misra, S.; A.K. Mohanty; L.T. Drzal; M. Misra; G. Hinrichsen. 2004. A Review on Pineapple Leaf Fibers, Sisal Fibers and Their Biocomposites. Macromol. Mater. Eng 289: 955-974.

Mohanty, A.K.; M. Misra; L.T. Drzal. 2002. Sustainable Biocomposites from Renewable Resources: Opportunities and Challenges in the Green Materials World. J. Polymers and the Environment 10 (1/2): 19-26.

Mohanty, S.; S.K. Nayak; S.K. Verma; S.S. Tripathy. 2004a. Effect of MAPP as Coupling Agent on the Performance of Sisal-PP Composites. Journal of Reinforced Plastics and Composites 23: 2047-2063.

Mohanty, S.; S.K. Verma; S.K. Nayak; S.S. Tripathy. 2004b. Influence of Fiber Treatment on the Performance of Sisal-polypropylene Composites. Journal of Applied Polymer Science 94: 1336-1345.

Mueller, D.H.; A. Krobjilowski. 2003. New Discovery in the Properties of Composites Reinforced with Natural Fibers. J. Industrial Textiles 33 (2): 111-123.

Munawar, S.S. 2008. Properties of Nonwood Plant Fiber Bundles and the Development of their Composites. Doctor dissertation, Graduate School of Agriculture, Kyoto University, Japan.

Mutje, P.; J. Girones; A. Lopez; M.F. Llop; F. Vilaseca. 2006. Hemp Strands:PP Composites by Injection Molding: Effect of Low Cost Physico-chemical Treatments. J. of Reinforced Plastics and Composites 25 (3): 313-327.

Nakagaito, A.N.; S. Iwamoto; H. Yano. 2005. Bacterial Cellulose: The Ultimate Nano-scalar Cellulose Morphology for the Production of High-strength Composites. Applied Physics A 80: 93-97.
Nakagaito, A.N.; H. Yano. 2004. The Effect of Morphological Changes from Pulp Fiber Towards Nano-scale Fibrilated. Applied Physics A 78: 547-552.

Nystrom, B.; R. Joffe; R . Langstorm. 2007. Microstructure and Strength of Injection Molded Natural Fiber Composites. J. of Reinforced Plastics and Composites 26 (6): 579-599.

Oksman, K.; M. Skrifvas; J.F. Selin. 2003. Natural Fibers as Reinforcement in Polylactic Acid (PLA) Composites. Composites Science and Technology 63: 1317-1324.

Okubo, K.; T. Fujii; E.T. Thostenson. 2009. Multi-scale Hybrid Biocomposite: Processing and Mechanical Characterization of Bamboo Fiber Reinforced PLA with Microfibrillated Cellulose. Composites: Part A 40: 469475.

Okubo, K.; T. Fujii; Y. Yamamoto. 2004. Development of Bamboo-based Composites and their Mechanical Properties. Composites: Part A 35:377-383.

Panthapulakkal, S.; M. Sain. 2007. Injection Molded Short Hemp Fiber/glass Fiber Reinforced Polypropylene Hybrid Composites-mechanical, Water Absorption and Thermal Properties. J. of App. Polymer Sci. 103:24322441.

Renner, M. 2008. Vehicle Production Rises, But Few Cars are "Green". http://www.worldwatch.org/node/5461.

Shibata, S.; Y. Cao; I. Fukumoto. 2008. Flexural Modulus of the Unidirectional and Random Composites Made from Biodegradable Resin and Bamboo and Kenaf Fibres. Composites Part A 39:640-646.

Subyakto; E. Hermiati; D.H.Y. Yanto; Fitria; I. Budiman; Ismadi; N. Masruchin; B. Subiyanto. 2009. Process Development to Produce Cellulose Nanofibers from Sisal (Agave sisalana) and Betung Bamboo (Dendrocalamus asper). Berita Selulosa 44 (2): 57-65.

Subyakto; E. Hermiati; D.H.Y. Yanto; N. Masruchin; Fitria; K.W. Prasetiyo; Ismadi. 2010. Biocomposites of Polylactic Acid Reinforced with Sisal or Bamboo Micro Fibers. Proceedings of the First International Symposium of Indonesian Wood Research Society 2-3 November 2009. pp. 106-110.

Suddell, B.C.; W.J. Evans. 2005. Natural Fiber Composites in Automotive Applications. In: Natural fibers, biopolymers, and biocomposites (Eds.: Mohanty, Misra, Drzal). CRC Press. pp. 231-260.

Suryanegara, L.; A.N. Nakagaito; H. Yano. 2009. The Effect of Crystallization of PLA on the Thermal and Mechanical Properties of Microfibrillated Cellulose Reinforced PLA Composites. Composites Science and Technology 69: 1187-1192.

Turbak, A.F.; F.W. Snyder; K.R. Sandberg. 1983. Microfibrillated Cellulose, A New Cellulose Product: Properties, Uses, and Commercial Potential. J Appl Polym Sci: Appl Polym Symp. 37: 815-827.

Wambua, P.; J. Ivens; I. Verpoest. 2003. Natural Fibres: Can They Replace Glass in Fibre Reinforced Plastics?. Composites Science and Technology 63: 1259-1264. 
Zhang, J.; H. Song, L. Lin; J. Zhuang; C. Pang; S. Liu. 2010. Microfibrillated Cellulose from Bamboo Pulp and Its Properties. Biomass and Bioenergy (2010), doi:10.1016/j.biocombioe.2010.06.013.

Zimmermann, T.; E. Pohler; T. Geiger. 2004. Cellulose Fibrils for Polymer Reinforcement. Advanced Engineering Materials 6 (9): 754-761.
Subyakto, Euis Hermiati, Nanang Masruchin, Ismadi, Kurnia Wiji Prasetiyo, Wida Banar Kusumaningrum, and Bambang Subiyanto

Research and Development Unit for Biomaterials Indonesian Institute of Sciences Jl. Raya Bogor Km 46, Cibinong, Bogor, Indonesia Tel/Fax : 021-87914511/021-87914510

E-mail : subyakto@biomaterial.lipi.go.id 